\title{
Interaksi Teknologi dan Tenaga Kerja: Peran Teknologi pada Daya Saing Produk (Studi Kasus Sentra Usaha Kecil dan Menengah Bordir Bangil Pasuruan)
}

\author{
Nur Faiza \\ Anita Kristina \\ Ilmu Ekonomi, Universitas Trunojoyo Madura, Indonesia \\ Korespondensi penulis: anita_amanda_ali@yahoo.com
}

\begin{abstract}
The purpose of this study is to analyze the role of technology in the production situation for competitiveness in small embroidery industries. It also relates to the analysis of choices for the use of technology and changes in the workforce situation. The study was conducted at the small embroidery industrial center in Bangil, Pasuruan, East Java, Indonesia. Data collection through in-depth interviews with informants business owners and workers. A qualitative phenomenological approach was used in this study. Data is processed and analyzed inductively. The findings are obtained that the technological needs in the production process cannot be avoided due to efforts to improve product competitiveness. The impact of these efforts forced business owners to rethink and manage their technology and workforce needs. The provision of technology is the main skill for workers so that workers also make efforts to improve the quality of embroidery with computer machines and complete orders on time. The implication of this research is expected to be able to provide enrichment in understanding the concept of sustain-ability of small businesses which is focused on the issue of choice of technology use and labor use.
\end{abstract}

Keywords: Embroidery industry; Labor; Production competitiveness; Technology.

Abstrak. Tujuan penelitian ini adalah untuk menganalisis peran teknologi dalam situasi
produksi sebagai kebutuhan daya saing pada industri kecil bordir. Hal ini terkait analisis
pilihan atas penggunaan teknologi dan perubahan situasi tenaga kerja. Penelitian ini
dilakukan pada sentra industri kecil Bordir yang ada di daerah Bangil, Kabupaten
Pasuruan, Jawa Timur. Pengumpulan data dilakukan melalui wawancara mendalam
dengan informan, yaitu pemilik usaha dan pekerja. Pendekatan kualitatif fenomenologi
digunakan dalam penelitian ini. Data diolah dan dianalisis secara induktif. Hasil temuan
dalam penelitian ini menunjukkan bahwa kebutuhan teknologi dalam proses produksi
tidak dapat dihindarkan sebagai akibat upaya pengusaha untuk memperbaiki daya saing
produksinya. Dampak dari upaya ini memaksa pemilik usaha untuk berpikir ulang dan
mengelola kembali kebutuhan teknologi dan tenaga kerjanya. Penguasaan teknologi
menjadi ketrampilan utama bagi pekerja, sehingga mereka juga melakukan upaya 
perbaikan kualitas produk bordir dengan mesin komputer dan menyelesaikan pesanan secara tepat waktu. Implikasi pada penelitian ini diharapkan mampu memberikan pengayaan pemahaman konsep keberlanjutan usaha kecil yang difokuskan pada pilihan penggunaan teknologi dan penggunaan tenaga kerja.

Kata kunci: Daya saing produksi; Industri bordir; Teknologi; Tenaga kerja.

\section{Article Info:}

Received: July 20, $2020 \quad$ Accepted: October 28, $2020 \quad$ Available online: February 16, 2021 DOI: http://dx.doi.org/10.30588/jmp.v10i2.717

\section{LATAR BELAKANG}

Perubahan yang memicu keterbukaan lingkungan bisnis dapat terjadi akibat perkembangan teknologi yang cepat. Hal ini menuntut pelaku bisnis untuk menjawab tantangan perubahan tersebut melalui upaya-upaya tertentu agar tetap bertahan dan mampu berdaya saing. Perusahaan yang gesit dengan kapasitas penyerapan tenaga kerja lebih inovatif akan memiliki kinerja produksi yang lebih tinggi dan mampu berdaya saing di pasar. Peningkatan daya saing dapat juga dilakukan melalui investasi mesinmesin yang berteknologi (Feder, 2018). Konsep daya saing produktivitas melekat pada transaksi dan interaksi teknologi (Flachenecker, 2018). Tuntutan kesiapan perusahaan/ pelaku bisnis membutuhkan upaya tertentu dan pengambilan keputusan yang tepat. Dengan demikian, kebutuhan strategi peningkatan daya saing dapat dimaknai sebagai perubahan struktur kerja, keputusan penggunaan input produksi, dan aktivitas pekerjaan.

Pekerjaan dalam aktivitas produksi, terlebih lagi jika terkait dengan barang seni, membutuhkan keterampilan/keahlian yang bersifat tradisonal dan ada pula yang beralih pada penggunaan mesin/teknologi. Produksi bordir adalah salah satu barang seni, sehingga produk tersebut membutuhkan sentuhan kreativitas. Pangsa pasar memaksa produk memiliki sentuhan kreativitas tinggi dan pemilik usaha akan berusaha memenuhinya melalui pengetahuan penjualan produk dan selera pasar. Sementara itu, peralihan penggunaan teknologi dapat membantu agar produk lebih bervariasi dan produktivitas meningkat (Hagsten \& Sabadash, 2017). Penggunaan teknologi juga memudahkan proses produksi dan membantu meningkatkan produksi dengan lebih cepat (Chiarvesio \& Romanello, 2018). Banyak perusahaan menengah juga merasakan manfaat teknologi dalam produktivitasnya (Bas \& Berthou, 2017).

Hal tersebut juga dirasakan oleh perusahaan penghasil produk yang berhubungan langsung dengan inovasi beragam. Misalnya, usaha kecil produk bordir pada industri bordir daerah di Bangil, Pasuruan, Jawa Timur. Produk bordir yang dihasilkan di daerah tersebut cukup beraneka ragam, di antaranya adalah produk mukena, kebaya bordir, sepatu bordir, baju bordir, baju taqwa, dan kopyah, sehingga agar produk-produk lainnya tetap memiliki daya saing, maka pemilik usaha bordir harus melakukan inovasi. Kecepatan pengetahuan kreasi bordir berjalan beriringan dengan selera pasar yang berubah-ubah, sehingga hal itu akan menjadi tantangan bagi pemilik usaha bordir untuk terus berkreasi dan berdaya saing sesuai keinginan pasar. 
Alasan peningkatan produktivitas dan daya saing memaksa pemilik usaha untuk memilih penggunaan mesin berteknologi, meskipun mereka akan menghadapi risiko, dalam bentuk penggunaan biaya tinggi, pengurangan jumlah tenaga kerja, atau perbaikan ketrampilan tenaga kerja atas teknologi yang digunakan. Pilihan-pilihan tersebut akan berdampak pada pengurangan tenaga kerja pada batas tertentu, dan pilihan atas penggunaan teknologi menjadi salah satu strategi yang dapat mempengaruhi situasi produksi dan tenaga kerja yang terlibat dalam proses produksinya (Özçam, 2019), Penggunaan teknologi baru akan memaksa pengusaha bordir untuk melakukan adopsi teknologi dan menjadi pilihan yang tidak terhindarkan bagi pemilik usaha.

Teknologi dan tenaga kerja dapat digunakan untuk saling melengkapi, tumbuh bersama, dan berjalan lebih efisien (Deming, 2017; Mariyono, 2018). Hal tersebut dapat dimaknai bahwa perubahan atas teknologi cenderung menghasilkan ketrampilan baru (inovasi dan difusi produk). Bahkan, perubahan tersebut dapat memuat lebih banyak nilai tambah yang tinggi, sehingga hal itu akan menyebabkan polarisasi pada tenaga kerja (ketrampilan dan upah). Interaksi peralatan kerja dan tenaga kerja dapat diterjemahkan pada peran masing-masing dalam proses produksi (Chaoji \& Martinsuo, 2019) menjadi peran yang saling melengkapi di antara keduanya. Namun, hal tersebut memuat konsekuensi adanya perbaikan ketrampilan tenaga kerja (Romão \& Nijkamp, 2019). Ketrampilan kreatif berkontribusi pada tumbuhnya ide-ide baru dan menjadi bagian dari investasi (Stojcic, Hashi, \& Orlic, 2018), karena hubungan antara teknologi dan ketrampilan pekerja cukup berdekatan dan berbasis pada ilmu pengetahuan (Goos, 2018; Mallick \& Sousa, 2017), serta membantu penyelesaian kompleksitas teknologi yang harus dikuasai pekerja.

Tabel 1. Jumlah Ekspor Produk UKM Indonesia ke Berbagai Negera

\begin{tabular}{cc}
\hline Tahun & Jumlah (Unit) \\
\hline 2017 & 8.100 \\
\hline 2018 & 9.300 \\
\hline 2019 & 10.200 \\
\hline
\end{tabular}

Sumber: Hasil penelitian pendahuluan yang diolah (2020).

Penelitian ini menganalisis peran teknologi pada situasi produksi bordir sebagai kebutuhan daya saing dan pilihan penggunaan teknologi dalam proses produksinya. Pemilik usaha berada pada situasi yang rumit, yakni mereka harus memilih untuk menggunakan input produksi berupa mesin produksi (teknologi) atau tidak. Keputusan atas pilihan tersebut memuat risiko bahwa jika mereka memilih untuk menggunakan mesin produksi baru (misalnya teknologi berbasis komputer), maka mereka harus menuntut pekerja mereka untuk meningkatkan ketrampilan, atau pilihan keputusan untuk menggunakan tenaga kerja yang berketrampilan saja, sehingga konsekuensinya adalah beberapa pekerja yang perannya dapat digantikan oleh pekerja berketrampilan sesuai kebutuhan produksinya. Selama ini, persoalan pada usaha kecil menengah (UKM) diselesaikan melalui pendekatan konsep manajemen (Anoraga, 2007). Namun, penelitian ini fokus pada interaksi teknologi mesin dan tenaga kerja dalam konsep ketenagakerjaan pada UKM. Penelitian ini dilakukan pada sentra industri kecil bordir yang terletak di daerah Bangil, Pasuruan, Jawa Timur. Berdasarkan hasil penelitian pendahuluan dan hasil observasi, beberapa produk UKM bordir ini telah dipasarkan 
hingga ke mancanegara, di antaranya ke berbagai negara-negara di Asia, seperti Malaysia, Singapura, Brunei Darussalam, Arab, dan Eropa. Tabel 1 menunjukkan data jumlah ekspor produk UKM yang telah diekspor ke luar negeri pada periode tahun 2017-2019.

Data pada Tabel 1 tersebut menjelaskan bahwa UKM telah mampu mengekspor produk UKM ke luar negeri dan mayoritas ekspor produk UKM tersebut adalah busana muslim batik, asesoris rumah dan wanita, serta kebaya. Bahkan, produk sepatu bordir sepanjang tahun 2019 mencapai 4.800 unit. Data jumlah ekspor produk dalam Tabel 1 didasarkan pada jawaban informan UKM yang diamati. Hal ini dikarenakan data lengkap dari dinas terkait belum lengkap atau mencukupi. Perubahan jumlah produk yang diekspor dalam tiga tahun terakhir menunjukkan penambahan yang cukup luar biasa. Hal itu membuktikan bahwa UKM bordir di Bangil masih cukup diminati oleh pembeli di luar negeri. Fenomena tersebut menguatkan persepsi bahwa UKM bordir di daerah Bangil Kabupaten Pasuruan harus mampu meningkatkan produktivitas sesuai permintaan konsumen.

Interaksi antara teknologi dan tenaga kerja pada penelitian ini dipahami sebagai peran masing-masing dalam menciptakan inovasi, efisiensi, dan produktivitas usaha. Pada akhirnya, upaya tersebut akan berkontribusi pada usaha yang dilakukan melalui peningkatan daya saing, karena teknologi dan tenaga kerja memainkan peran penting dalam membentuk daya saing produk (Jacinto, Ribeiro, \& Cravo, 2017). Penelitian ini akan menjawab permasalahan mengenai bagaimana peran teknologi dalam proses produksi bordir dan upaya apa yang dapat dilakukan oleh pengusaha UKM bordir untuk menggunakan pilihan kombinasi antara mesin/teknologi dan tenaga kerja agar mereka tetap berdaya saing. Kontribusi penelitian ini adalah memberikan pengayaan pemahaman konsep keberlanjutan UKM yang difokuskan pada persoalan pilihan strategi penggunaan teknologi dan tenaga kerja. Secara praktis, temuan penelitian ini berkontribusi pada pemahaman bahwa kompleksitas persoalan dalam sebuah situasi lingkungan bisnis dapat terjadi karena pilihan yang berat dan dilematis, karena pilihan penggunaan antara teknologi dan tenaga kerja semakin tidak dapat dihindari.

\section{KAJIAN TEORITIS}

\section{Inovasi Teknologi dalam Produksi Usaha Kecil Menengah}

Pelaku industri seharusnya memiliki kemampuan daya saing bisnis agar mampu mencapai posisi yang menguntungkan. Daya saing memiliki makna sebagai kekuatan dan kata "saing" dapat diartikan mencapai lebih dari yang lain, atau berbeda dengan yang lain, atau memiliki keunggulan tertentu dibanding lainnya (Sumihardjo, 2008). Artinya, daya saing bermakna sebagai kekuatan untuk berusaha menjadi unggul dalam hal tertentu yang dilakukan oleh seseorang, kelompok, instansi, atau perusahaan tertentu. Indikator daya saing suatu perusahaan terdiri atas biaya (cost), kualitas (quality), waktu penyampaian (delivery), dan fleksibilitas (flexibility). Keempat indikator tersebut dijelaskan lebih lanjut sebagai berikut (Muhardi \& Lies,2007):

a. Biaya merupakan indikator daya saing operasi yang meliputi empat hal, yaitu biaya produksi, produktivitas tenaga kerja, penggunaan kapasitas produksi, dan persediaan. Biaya sebagai unsur daya saing merupakan modal yang mutlak dimiliki oleh perusahaan dan mencakup pembiayaan produksinya, produktivitas tenaga kerjanya, peman- 
faatan kapasitas produksi perusahaan, dan adanya cadangan produksi (persediaan) yang sewaktu-waktu dapat digunakan oleh perusahaan untuk menunjang kelancaran perusahaan tersebut.

b. Kualitas merupakan dimensi daya saing yang meliputi berbagai indikator di antaranya tampilan produk, jangka waktu penerimaan produk, daya tahan produk, kecepatan penyelesaian keluhan konsumen, dan kesesuaian produk terhadap spesifikasi disain. Tampilan produk dapat tercermin dari disain produk atau layanannya. Tampilan produk yang baik memiliki disain sederhana, tetapi tampilan tersebut mempunyai nilai yang tinggi. Jangka waktu penerimaan produk dimaksudkan dengan lamanya umur produk dapat diterima oleh pasar. Semakin lama umur produk di pasar menunjukkan kualitas produk tersebut semakin baik. Ada pun daya tahan produk dapat diukur dari umur ekonomis penggunaan produk.

c. Waktu penyampaian merupakan dimensi daya saing yang meliputi berbagai indikator di antaranya ketepatan waktu produksi, pengurangan waktu tunggu produksi, dan ketetapan waktu penyampaian produk. Ketiga indikator tersebut berkaitan, sehingga ketepatan waktu penyampaian produk dapat dipengaruhi oleh ketepatan waktu produksi dan lamanya waktu tunggu produksi.

d. Fleksibilitas merupakan dimensi daya saing yang meliputi berbagai indikator di antaranya berbagai macam produk yang dihasilkan dan kecepatan menyesuaikan dengan kepentingan lingkungan.

Salah satu cara untuk meningkatkan daya saing industri adalah inovasi, baik melalui inovasi proses maupun inovasi produk. Menurut Schilling (2015), inovasi proses merupakan sebuah cara yang dilakukan oleh pengusaha dalam menjalankan bisnisnya untuk meningkatkan efektivitas atau efisiensi proses produksi. Menurut Porter (2011), suatu negara memperoleh keunggulan daya saing, apabila perusahaan (yang ada di negara tersebut) kompetitif.

\section{Daya Saing dan Produktivitas}

Daya saing suatu negara ditentukan oleh kemampuan industrinya melakukan inovasi dan meningkatkan kemampuannya. Empat faktor utama yang menentukan daya saing suatu komoditas adalah kondisi faktor (factor condition), seperti tenaga trampil dan prasarana; kondisi permintaan (demand condition) dan tuntutan mutu dalam negeri untuk hasil industri tertentu; industri terkait dan industri pendukung yang kompetitif (related and supporting industry); serta kondisi struktur, persaingan, dan strategi industri (firm strategy, structure, and rivalry). Keempat faktor tersebut didukung oleh peranan peluang dan pemerintah dalam meningkatkan keunggulan daya saing industri nasional dan secara bersama-sama faktor-faktor tersebut membentuk sistem yang dikenal sebagai Porter's Diamond Theory (Porter, 2011). Hal tersebut dibuktikan oleh studi empiris oleh Morris (2018) yang menemukan bahwa upaya inovasi, intensitas modal perusahaan, dan modal manusia berperan penting dalam inovasi produk dan proses, sehingga hal itu berdampak signifikan dalam meningkatkan produktivitas usaha.

Produktivitas memiliki banyak konsep, di antaranya adalah konsep produktivitas secara umum yang dimaksudkan untuk menyediakan semakin banyak barang dan jasa dalam pemenuhan kebutuhan sebanyak mungkin orang dengan menggunakan sesedikit mungkin sumber daya (Anoraga, 2007). Menurut Hasibuan dan Hasibuan (2016), produktivitas merupakan perbandingan antara keluaran (output) dan masukan (input), 
serta mengutamakan cara untuk memanfaatkan sumber-sumber dengan baik dalam memproduksi barang atau jasa. Inovasi teknologi dalam proses produksi dapat berdampak pada permintaan tenaga kerja.

\section{Tenaga Kerja}

Permintaan tenaga kerja berkaitan dengan jumlah tenaga kerja yang dibutuhkan oleh perusahaan atau instansi tertentu dipengaruhi oleh perubahan tingkat upah dan faktor-faktor lain yang mempengaruhi permintaan hasil produksi, antara lain naik turunnya permintaan pasar terhadap hasil produksi dari perusahaan tercermin melalui besar kecilnya volume produksi dan harga barang-barang modal, yaitu nilai mesin atau alat yang digunakan dalam proses produksinya.

Menurut Danquah dan Amankwah-Amoah (2017), permintaan tenaga kerja terdiri atas lima faktor, yaitu (1) Tingkat upah, yaitu jumlah optimal tenaga kerja yang digunakan dapat diperhitungkan dengan melihat tingkat upah. Jika tingkat upah rendah, maka tenaga kerja yang diminta akan cenderung semakin banyak atau sebaliknya; (2) Teknologi yang digunakan untuk mempengaruhi kemampuan menghasilkan produk. Ketika tingkat teknologi yang digunakan semakin efektif, maka tenaga kerja dapat lebih mengaktualisasikan kemampuan dan ketrampilannya; (3) Produktivitas, yaitu modal yang digunakan dapat berpengaruh terhadap tingkat produktivitas tenaga kerja. Semakin tinggi modal yang dimiliki dapat meningkatkan produktivitas tenaga kerja; (4) Kualitas tenaga kerja yang dapat diukur melalui latar belakang pendidikan dan pengalaman kerjanya. Semakin tinggi tingkat pendidikan dan semakin berpengalaman tenaga kerja, maka permintaan tenaga kerja juga akan semakin banyak; (5) Fasilitas modal merupakan output yang dihasilkan dengan adanya modal dan tenaga kerja yang tidak dipisahkan. Karena peranan faktor lain dapat menjadi faktor penentu lainnya, maka perubahan teknologi akan membutuhkan ketrampilan kerja di pasar tenaga kerja. Ketrampilan tenaga kerja diartikan sebagai kapasitas individu yang pada hakikatnya dibentuk oleh keahlian, yaitu hal-hal yang bersifat intelektual dan fisik (Robbins, 2006).

Revolusi teknologi dapat menciptakan barang dan jasa yang baru dan mengubah bagaimana dan di mana produk tersebut dihasilkan (Robbins, 2006). Perdagangan internasional dan pembagian kerja berubah secara signifikan. Teknologi baru berbeda dengan revolusi industri yang dikembangkan secara spesifik melalui sebuah aplikasi. Selanjutnya, setiap mesin memiliki satu tugas dengan beberapa pengecualian. Sekarang ini, sebagian besar mesin yang berbasis teknologi baru dapat diprogram untuk melakukan lebih dari satu tugas. Tidak seperti inovasi teknologi seabad sebelumnya, teknologi baru sekarang ini membutuhkan lebih sedikit tenaga kerja untuk mengembangkan dan memproduksi perangkat kerasnya, tetapi teknologi tersebut lebih banyak dibutuhkan untuk mengembangkan dan memproduksi perangkat lunak aplikasi (Schilling, 2015).

Kombinasi pertumbuhan teknologi tinggi untuk produksi dan penerapannya pada struktur permintaan atas ketrampilan tenaga kerja akan terjadi ketika ekonomi berkembang. Teknologi membutuhkan lebih sedikit tenaga kerja untuk menghasilkan barang dan jasa daripada yang seharusnya diperlukan. Teknologi baru akan mempengaruhi pertumbuhan ekonomi semua negara, pekerjaan, dan upah. Sementara itu, penggunaan teknologi dibawa ke dalam proses produksi untuk meningkatkan produktivitas dan pengendalian kualitas, serta menciptakan kemungkinan untuk menghasilkan barang dan jasa yang baru. Jika dikaitkan dengan teknologi, maka proses produksi akan membu- 
tuhkan tenaga kerja dengan tingkat pendidikan yang relatif tinggi, manajemen angkatan kerja (baik pria maupun wanita), dan ketersediaan upah yang berbasis pada ilmu pengetahuan (Rosenberg \& Nathan, 1982). Dengan demikian, kualitas tenaga kerja akan mengikuti kemauan teknologi. Agar transfer teknologi benar-benar terjadi, maka tenaga kerja dituntut untuk "belajar dengan menggunakan teknologi" (Rosenberg \& Nathan, 1982). Adaptasi produksi perlu diimplementasikan dan menjadi upaya untuk mengadaptasi pengendalian kualitas.

Menurut sebuah studi yang dilakukan oleh International Labour Organization (ILO) mengenai Association of Southeast Asian Nations (ASEAN) (ILO, 2013), lebih dari 60 persen pekerjaan berupah di bidang elektronika, otomotif, dan tekstil, serta pakaian jadi terancam dan mungkin akan hilang karena otomatisasi. Persentase pekerjaan yang berisiko kini mencapai 85 persen pada perdagangan retail (ILO, 2013). Secara keseluruhan, hasil temuan studi tersebut menunjukkan bahwa semua pekerjaan mengalami otomatisasi di ASEAN-5 beberapa dasawarsa ke depan, yaitu Kamboja, Indonesia, Thailand, Filipina, dan Vietnam. Dari kelima negara ASEAN tersebut, risiko pekerjaan yang mengalami otomatisasi tertinggi adalah Vietnam (70\%), diikuti Filipina (57\%), dan Indonesia menyusul pada angka 56\% (ILO, 2013). Probabilitas hilangnya pekerjaan di Thailand adalah yang terkecil, yaitu 44\%, sehingga perkiraan untuk Indonesia dan negara-negara ASEAN lain terdapat pekerjaan yang berisiko tergantikan oleh mesin dan otomatisasi. Pekerjaan tersebut termasuk pekerjaan yang membutuhkan persepsi dan manipulasi, kecerdasan kreatif, dan kecerdasan sosial. Studi empiris membuktikan bahwa sumber daya manusia akan memberikan dampak positif dan signifikan secara statistik pada perubahan efisiensi (adopsi teknologi), sedangkan sumber daya manusia memainkan peran penting dalam peningkatan tingkat adopsi teknologi yang dialami oleh negara-negara di ASEAN (Danquah \& Amankwah-Amoah, 2017)

\section{METODE PENELITIAN}

Fokus permasalahan dalam penelitian ini adalah persoalan peran teknologi dalam situasi lingkungan bisnis yang dihadapi oleh UKM bordir di daerah Bangil, Pasuruan, Jawa Timur dan upaya yang dilakukan pemilik atau pelaku usaha dalam strategi pemilihan penggunaan teknologi dan tenaga kerja. Pemilik usaha diharuskan untuk memilih menggunakan kombinasi antara mesin/teknologi dan tenaga kerja supaya pemilik tetap memiliki daya saing. Pengumpulan data dalam penelitian ini dilakukan melalui teknik observasi, wawancara mendalam dengan informan, dan dokumentasi. Sampel dalam penelitian ini menggunakan metode purposive sampling, yakni penentuan sampel bertujuan.

Informan dalam penelitian ini adalah pemilik usaha dan pekerja bordir di Sentra Bordir Bangil, Kabupaten Pasuruan, Provinsi Jawa Timur. Informan dipilih berdasarkan teknik purposive sampling dengan cara dipilih secara sengaja berdasarkan kriteriakriteria tertentu, yaitu pemilihan informan untuk pemilik usaha dilihat dari lama usahanya minimal tiga tahun dan jenis mesin produksi bordir yang digunakan, sedangkan untuk kriteria pekerja adalah mereka yang menggunakan mesin komputer. Jenis mesin bordir yang digunakan adalah mesin komputer dan mesin juki. Mesin bordir komputer adalah sebuah alat yang dapat melakukan bordir atau menyulam tanpa menggunakan tangan, yaitu mesin bordir yang dipandu program komputer untuk membuat pola di atas kain dengan hiasan berbahan benang. Di sisi lain, mesin juki 
adalah mesin bordir yang digerakkan oleh tangan sumber daya manusia atau dilakukan secara manual. Informan yang digunakan dalam penelitian ini berjumlah delapan orang yang terdiri atas empat orang pemilik usaha dan empat orang perwakilan pekerja bagian bordir. Pemilik usaha sebagai orang yang memiliki kewenangan atas pengelolaan sebuah usaha dan pekerja bagian bordir sebagai pekerja yang menjalankan langsung proses produksi, maka keduanya diyakini mampu memberikan informasi mendalam dan menjawab pertanyaan penelitian.

Data dianalisis menggunakan metode induktif melalui pendekatan kualitatif fenomenologi. Pendekatan fenomenologi adalah cara pandang penelitian yang didasarkan pada kontekstual yang mengarah pada pola-pola fenomena tertentu (Creswell, 2010). Proses penelitian pada pendekatan ini diawali dengan observasi melalui penelitian pendahuluan, pengumpulan data, analisis data, dan memaknai jawaban informan yang dikaitkan dengan teori atau hasil penelitian lain. Selanjutnya, penelitian ini menyimpulkan atas temuan-temuan tersebut. Penelitian ini mengkaji fenomena sosial atas persoalan perubahan lingkungan bisnis, yaitu munculnya mesin bordir komputer dan dampaknya terhadap keputusan penggunaan tenaga kerja dan teknologi mesin bordir yang ada. Data penelitian diuji keabsahannya dengan menggunakan uji kredibilitas. Disain uji keabsahan dilakukan melalui eksplorasi diskusi (Creswell, 2010) yang menggunakan beberapa teori meliputi teori tenaga kerja, daya saing, dan teknologi. Uji validitas data juga dilakukan melalui teknik triangulasi sumber dan informasi. Teknik triangulasi adalah uji keabsahan data yang diperoleh dalam pengumpulan data (Creswell, 2010), sedangkan disain triangulasi dilakukan melalui cross-check jawaban yang diperoleh antarinforman (Creswell, 2010).

\section{HASIL DAN PEMBAHASAN}

Penelitian ini menganalisis peran teknologi dalam situasi produksi sebagai kebutuhan daya saing pada industri kecil bordir di Sentra Bordir Bangil, Kabupaten Pasuruan, Provinsi Jawa Timur. Penelitian dilakukan dengan mengumpulkan data primer melalui teknik wawancara dengan delapan orang informan. Tabel 2 menunjukkan identifikasi informan yang dipilih secara purposive dalam penelitian ini. Identifikasi ini dilakukan untuk menggambarkan karakteristik informan yang dipilih.

Tabel 2. Identifikasi Informan

\begin{tabular}{lccclc}
\hline Informan & Gender & $\begin{array}{c}\text { Jenis } \\
\text { Mesin }\end{array}$ & $\begin{array}{c}\text { Lama } \\
\text { Usaha/Kerja } \\
\text { (Tahun) }\end{array}$ & Pendidikan & Omset/Upah per bulan (Rp) \\
\hline Pemilik 1 & L & K \& J & 18 & Sarjana & $225.000 .000-250.000 .000$ \\
\hline Pemilik 2 & L & K \& J & 35 & SMA & $230.000 .000-250.000 .000$ \\
\hline Pemilik 3 & P & J & 11 & Sarjana & $25.000 .000-35.000 .000$ \\
\hline Pemilik 4 & P & J & 14 & Sarjana & $50.000 .000-80.000 .000$ \\
\hline Pekerja 1 & L & K/J & 10 & SMK & 1.800 .000 \\
\hline Pekerja 2 & P & J & 8 & SMP & 1.000 .000 \\
\hline Pekerja 3 & P & J & 12 & SMP & 1.000 .000 \\
\hline Pekerja 4 & L & K/J & 22 & SMK & 1.800 .000 \\
\hline Kena
\end{tabular}

Keterangan: L=Laki-laki; P=Perempuan; $\mathrm{K}=$ Mesin komputer; J=Mesin juki.

SMA=Sekolah Menengah Atas; SMK=Sekolah Menengah Kejuruan; SMP=Sekolah Menengah Pertama.

Sumber: Hasil pengumpulan data primer yang diolah (2020). 
Hasil penelitian ini ditunjukkan dari temuan-temuan yang diperoleh melalui proses wawancara. Proses pengolahan dan analisis data dilakukan melalui pemaknaan jawaban informan yang dikaitkan dengan teori maupun hasil penelitian lain sebelumnya. Dengan demikian, penggunaan teori maupun hasil penelitian sebelumnya dimaksudkan pula untuk melakukan pengujian kredibilitas dan validitas data yang diperoleh. Proses tersebut ditunjukkan pada penyajian analisis data, yakni menyajikan informasi dari para informan yang dilakukan cross-check dengan jawaban informan lain, maupun beberapa teori dan hasil penelitian sebelumnya yang relevan.

\section{Peran Teknologi dalam Proses Produksi}

Kebutuhan teknologi dalam proses produksi tidak dapat dihindarkan akibat upaya meningkatkan daya saing produksi. Hal tersebut dikarenakan terdapat perubahan pada kapasitas produksi bordir yang ada selama ini. Gambaran tersebut sebagaimana pernyataan pemilik usaha produksi bordir kopyah sebagai berikut:

"Jumlah produksi dalam sehari lek gae komputer 1 anak seng finising sekitar 100-300 kodi, lek e gae mesin juki sehari 1 arek cuman atok 30-40 kodi (jumlah produksi dalam sehari menggunakan mesin komputer setiap pekerja mencapai sekitar 100-300 kodi, sedangkan penggunaan mesin juki dalam sehari hanya menghasilkan 30-40 kodi untuk setiap pekerja)" (Pemilik 1).

Begitu pula, pernyataan pemilik usaha bordir produksi baju sebagai berikut:

"Jumlah produksi komputer tidak sampai sehari bisa menghasilkan 44 potong, kalau menggunakan mesin biasa bisa sampai 2-4 hari” (Pemilik 2).

Berdasarkan pernyataan tersebut, maka perubahan teknologi yang mampu meningkatkan jumlah kapasitas yang dihasilkan dari produksi melalui komputer. Pembaruan mesin-mesin produksi dengan menggunakan teknologi modern memiliki dampak positif bagi peningkatan hasil produksi untuk mencapai skala hasil produksi yang optimal (Wibowo \& Nugroho, 2018). Berdasarkan konsep produktivitas universal, produsen berupaya untuk menyediakan semakin banyak barang dan jasa bagi pemenuhan kebutuhan semakin banyak orang dengan menggunakan sesedikit mungkin sumber daya mereka (Anoraga, 2007). Berdasarkan konsep tersebut, teknologi baru cenderung membuat tingkat produktivitas usaha meningkat. Upaya untuk meningkatkan keefektifan, mesin-mesin produksi seharusnya memiliki umur ekonomis yang panjang, sehingga upaya untuk merawat mesin produksi dapat dilakukan melalui cara pemeliharaan dan perawatan mesin secara berkala serta menetapkan jadwal dan pengontrolan rutin terhadap pelumas.

Selain itu, penggunaan teknologi (mesin komputer) pada usaha bordir juga dapat mengurangi biaya produksi lebih besar bagi pemilik usaha dibandingkan penggunaan mesin manual. Hal ini dikarenakan adanya biaya upah pekerja untuk penggunaan mesin manual. Pada umumnya, biaya upah memiliki nilai lebih tinggi dibandingkan dengan biaya perawatan mesin. Hal tersebut sesuai dengan pernyataan informan berikut ini:

"Biaya produksi kalau pakai mesin komputer ya jadi berkurang mbak, beda kalau pakai mesin juki, biayanya mahal soalnya pekerja yang dibutuhkan banyak mbak" (Pekerja 1).

Pernyataan tersebut juga didukung oleh pernyataan informan lainnya, yaitu:

"Semakin banyak hasil bordir yang dihasilkan, maka biaya produksinya bisa semakin murah" (Pekerja 2). 
Jawaban informan tersebut dapat dimaknai bahwa penggunaan teknologi baru (mesin bordir komputer) tersebut mampu mengurangi biaya produksi, sehingga pengeluaran perusahaan dapat lebih efisien dan lebih produktif secara keseluruhan. Hal ini sesuai yang dijelaskan oleh Hasibuan \& Hasibuan (2016) yang menyatakan bahwa produktivitas merupakan perbandingan antara keluaran (output) dan masukan (input), serta mengutamakan cara memanfaatkan sumber-sumber daya perusahaan untuk memproduksi barang atau jasa dengan baik. Peningkatan produktivitas faktor produksi yang terdiri atas tenaga kerja dan mesin memberikan dampak pada biaya-biaya yang dikeluarkan perusahaan semakin menurun. Hal ini didukung dengan hasil penelitian Özçam (2019) yang menyimpulkan bahwa jika teknologi meningkat secara cepat seiring waktu, maka batas biaya produksi marginal akan semakin rendah, sehingga hal itu dapat menentukan batas bawah harga produk dan batas atas kuantitas output.

Adanya pengaruh tingkat keefektifan dan efisiensi dalam proses produksi akan membuat pemilik usaha bordir melakukan upaya peningkatan inovasi produksi agar mereka mampu bersaing di pasar. Kondisi tersebut mendorong pemilik usaha bordir melakukan upaya peningkatan inovasi disain bordir yang bertujuan untuk meningkatkan daya saing produk mereka di pasar dan meningkatkan minat konsumen. Hal itu sebagaimana pernyataan informan sebagai berikut:

"Kalo inovasi itu pasti... sama harganya juga. Misalkan, mukena mahal........ biasanya kan ada tasnya.... kita bentuk model tas yang lucu-lucu dan unik. Ada yang model tas ransel juga. Ada mukena yang kita kasih swarovski (hiasan manik-manik)” (Pemilik 3).

Begitu juga pernyataan informan lainnya, sebagai berikut:

"Inovasi produk biasanya saya mengkreasikan bentuk kopyahnya dengan bentukbentuk yang bermacam-macam, seperti kopyah ainun najib, serta kopyah palestin......" (Pemilik 4).

Pernyataan informan berikut ini juga memperkuat pernyataan informan lainnya, yaitu:

"Disain yang digunakan bordir dikolaborasi dengan disain yang sudah ada, kemudian diberi sentuhan bahan lain seperti kolaborasi dengan batik” (Pemilik 2).

Berdasarkan pernyataan-pernyataan informan tersebut, pemilik usaha bordir melakukan inovasi disain yang sudah ada dan digabungkan dengan sentuhan lain, seperti batik. Dengan cara itu, produk bordir diharapkan oleh pemilik usaha agar mampu eksis di pasar, sehingga untuk meningkatkan daya saing bisnis dalam konteks global, pemilik usaha harus mampu melakukan strategi khusus, yaitu strategi inovasi administrasi, inovasi teknis, inovasi proses, dan inovasi produk. Berdasarkan strategi tersebut, pertimbangan utama untuk meningkatkan daya saing bisnis adalah kemajuan teknologi dan metode baru dalam proses produksi (Riyadi \& Sumardi, 2017). Penggunaan teknologi menjadi salah satu faktor dalam meningkatkan produksi dalam industri bordir ini. Jika hal itu dikaitkan dengan IKM bordir, maka industri ini dapat disebut sebagai upaya pemberdayaan masyarakat. Upaya pemberdayaan tersebut dapat dianggap sebagai kegiatan identifikasi dan implementasi teknologi tepat guna, serta pendampingan pengelolaan usaha, sehingga upaya peningkatan produktivitas dapat dicapai, produk yang dihasilkan lebih baik dari sisi estetika karena lebih presisi, dan proses pengerjaan bisa lebih cepat sehingga penyelesaian produk dapat lebih tepat waktu sesuai pesanan. 


\section{Pilihan Penggunaan Teknologi dan Tenaga Kerja}

Hasil temuan di lapangan menunjukkan bahwa dampak penggunaan teknologi baru ini akan memaksa pemilik usaha untuk berpikir ulang dan mengelola kembali kebutuhan teknologi dan tenaga kerjanya. Pemilik usaha dapat melakukan kombinasi ulang dengan mengatur input apa saja yang mengalami perubahan atau pengurangan. Dengan adanya kombinasi input baru, yaitu teknologi mesin bordir komputer menyebabkan perusahaan membutuhkan pekerja yang memiliki keahlian tertentu dalam penggunaan mesin komputer. Sebagaimana pernyataan yang disampaikan oleh informan berikut ini:

"Saya lebih mencari pekerja baru yang minimal harus bisa mengoperasikan komputer" (Pemilik 1).

Pernyataan tersebut diperkuat oleh pernyataan informan lainnya, yaitu:

\section{"Pekerjanya harus tahu komputer, tahu teknik komputer" (Pemilik 3).}

Berdasarkan pernyataan informan tersebut, maka upaya pemilik usaha dengan adanya perubahan pada penggunaan teknologi komputer membuat pemilik usaha berpikir ulang untuk mencari pekerja baru yang menguasai dan mampu menggunakan teknologi (mesin bordir komputer). Penggunaan komputer pada mesin bordir sudah dikenal oleh pengusaha sejak tahun 2004. Berdasarkan hasil pengamatan, hampir $80 \%$ usaha bordir saat ini telah menggunakan mesin komputer. Hal ini disebabkan adanya permintaan dan inovasi disain produk bordir yang digemari masyarakat (konsumen) beralih pada bordir komputer. Peralihan penggunaan dari teknologi sederhana (mesin bordir juki) ke penggunaan mesin komputer akan mempengaruhi keputusan pengusaha dalam penggunaan tenaga kerja. Menurut Wiltshire (2018), faktor-faktor yang mempengaruhi permintaan tenaga kerja dapat didefinisikan melalui beberapa faktor, di antaranya teknologi yang digunakan dapat mempengaruhi kemampuan untuk menghasilkan produknya.

Ketika tingkat teknologi yang digunakan semakin efektif, tenaga kerja dapat lebih mengaktualisasikan kemampuan dan ketrampilannya. Permintaan tenaga kerja berkaitan dengan jumlah tenaga kerja yang dibutuhkan oleh perusahaan atau instansi tertentu. Biasanya, permintaan tenaga kerja yang dipengaruhi oleh perubahan tingkat upah dan perubahan faktor-faktor lain yang mempengaruhi permintaan hasil produksi, antara lain naik turunnya permintaan pasar akan hasil produksi yang tercermin melalui besarnya volume produksi dan harga barang-barang modal, yaitu nilai mesin atau alat yang digunakan dalam proses produksi. Menurut Robbins (2006), ketrampilan kerja diartikan sebagai kapasitas individu untuk mengerjakan berbagai tugas dalam suatu pekerjaan yang meliputi seluruh kemampuan individual yang pada hakikatnya dibentuk oleh keahlian, yaitu hal-hal yang bersifat intelektual dan fisik.

Dengan pilihan pergantian teknologi, pekerja juga melakukan upaya perbaikan kualitas kerjanya, yakni mereka belajar membordir menggunakan mesin komputer dan menyelesaikan pesanan tepat waktu. Sebagaimana pernyataan informan berikut ini:

"Saya berusaha mengerjakan bordiran sesuai target mbak, sama menggunakan benang yang bagus" (Pekerja 3).

Pernyataan tersebut didukung oleh informan lainnya yang menyatakan: 
"Kalau saya membordir itu pakai benang yang bagus mbak, supaya bordirannya tidak cepat berodol mbak..... Kalau gak ada gangguan, biasanya saya mengerjakan bordiran tepat waktu mbak" (Pekerja 4).

Jawaban informan tersebut dapat dimaknai bahwa penguasaan teknologi menjadi ketrampilan utama bagi pekerja. Pekerja melakukan upaya menyelesaikan pesanan tepat waktu. Upaya tersebut sesuai dengan salah satu indikator daya saing perusahaan di antaranya ketepatan waktu produksi, pengurangan waktu tunggu produksi, dan ketetapan waktu penyampaian produk. Ketiga indikator waktu tersebut berkaitan satu sama lain. Ketepatan waktu penyampaian produk dipengaruhi oleh ketepatan waktu produksi dan lamanya waktu tunggu produksi, sehingga tingkat kedisiplinan kerja yang baik mencerminkan kredibilitas karyawan mencapai hasil kerja yang optimal untuk kesuksesan perusahaan (Hasibuan \& Hasibuan, 2016).

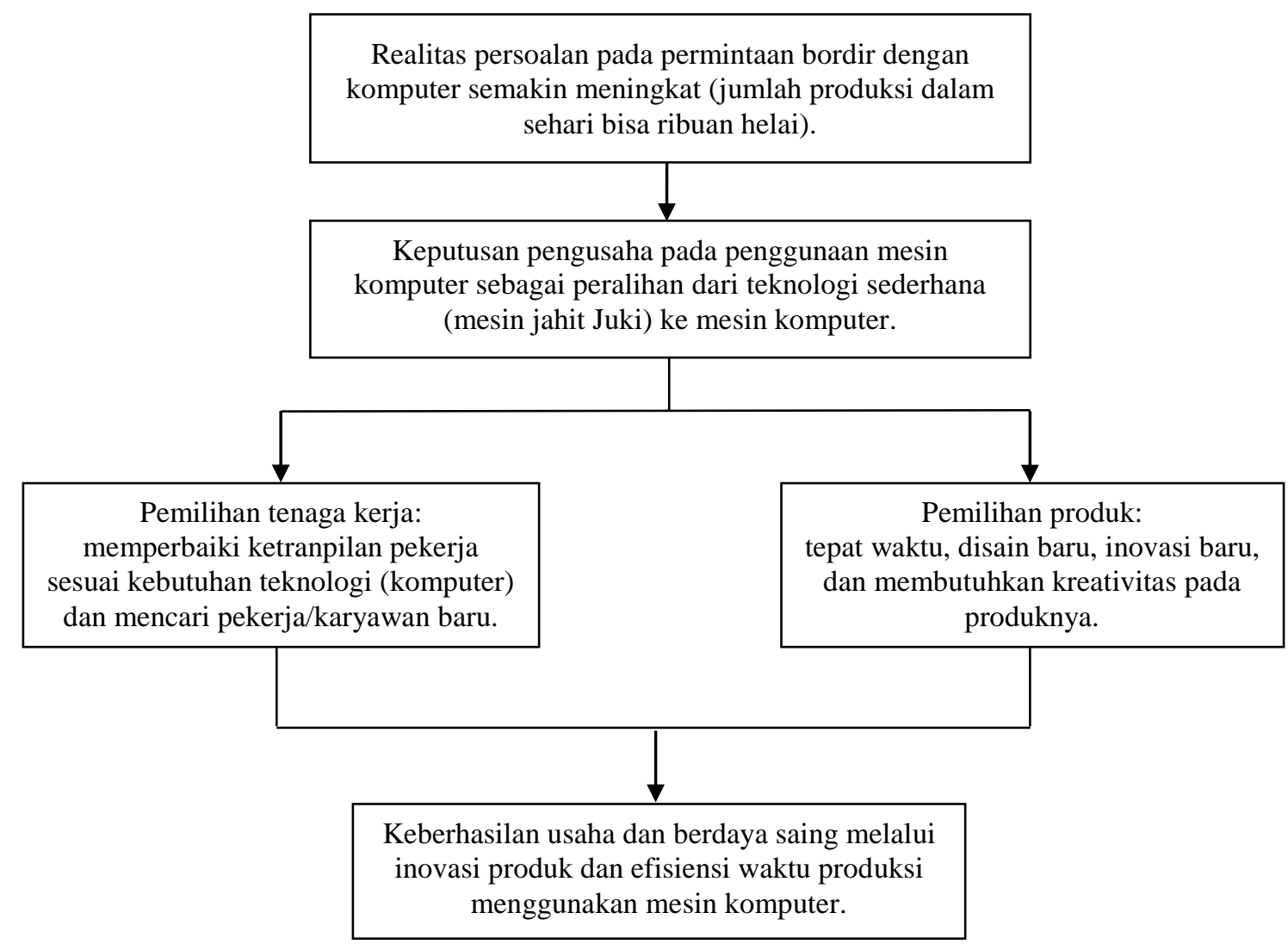

Sumber: Rangkuman hasil temuan penelitian diolah (2020).

\section{Gambar 1. Temuan Penelitian Secara Keseluruhan}

Upaya yang dilakukan pekerja untuk melakukan perbaikan kualitas adalah menggunakan bordir mesin komputer dan bahan baku benang yang berkualitas. Hal tersebut merupakan salah satu indikator daya saing perusahaan, yaitu kualitas produk merupakan dimensi daya saing yang sangat penting dan meliputi berbagai indikator, di antaranya tampilan produk, jangka waktu penerimaan produk, daya tahan produk, kecepatan penyelesaian keluhan konsumen, dan kesesuaian produk terhadap spesifikasi disain (Hasibuan \& Hasibuan, 2016). Tampilan produk dapat tercermin dari disain produk atau 
layanannya, sehingga tampilan produk yang baik adalah disain sederhana yang bernilai tinggi. Jangka waktu penerimaan produk dimaksudkan sebagai lamanya umur produk yang dapat diterima oleh pasar, semakin lama umur produk di pasar menunjukkan kualitas produk tersebut semakin baik. Ada pun daya tahan produk dapat diukur dari umur ekonomis penggunaan produk tersebut. Beberapa temuan dalam penelitian ini mengenai peran teknologi dalam proses produksi dan pilihan penggunaan teknologi dan tenaga kerja digambarkan dalam bentuk bagan alir pada Gambar 1.

Berdasarkan Gambar 1, temuan pada penelitian ini secara keseluruhan membuktikan bahwa pengusaha tidak dapat mengelak akan kebutuhan penggunaan teknologi komputer pada usaha. Temuan atas peningkatan kualitas produksi dengan menggunakan mesin komputer berkaitan juga dengan menjaga kualitas bahan baku. Kualitas bahan baku berpengaruh positif dan signifikan terhadap kualitas produk (Sentosa \& Trianti, 2019). Kualitas produk merupakan kunci penting bagi perusahaan untuk menjaga kepuasan pelanggan. Namun, pilihan atas penggunaan teknologi akan membawa konsekuensi upaya lainnya, yakni upaya memperbaiki ketrampilan pekerja, atau mencari pekerja baru yang lebih menguasai penggunaan mesin bordir komputer. Konsekuensi berikutnya adalah upaya untuk menyelesaikan produk bordir dengan tepat waktu dan menjaga kualitas produksi melalui cara inovatif dan kreatif. Dengan demikian, pilihan atas penggunaan teknologi komputer ini diyakni pengusaha sebagai upaya menuju keberhasilan usaha dan berdaya saing.

\section{KESIMPULAN DAN SARAN}

Teknologi berperan penting untuk meningkatkan daya saing dan memenuhi permintaan hasil produksi bordir. Kebutuhan teknologi dalam proses produksi tidak dapat dihindarkan sebagai akibat upaya memperbaiki daya saing produksi. Permintaan produk bordir dengan mesin komputer semakin meningkat. Dengan demikian, pemilik usaha melakukan inovasi pada disain yang sudah ada digabungkan dengan sentuhan lain seperti batik. Dengan sentuhan kreasi baru tersebut, produk bordir yang dihasilkan oleh pemilik usaha diharapkan masih mampu eksis di pasar.

Dampak dari upaya ini akan memaksa pemilik usaha untuk berpikir ulang dan mengelola kembali kebutuhan teknologi dan tenaga kerjanya. Pemilik melakukan kombinasi ulang untuk mengatur input apa saja yang akan mengalami perubahan atau pengurangan. Dengan kombinasi input baru berupa teknologi komputer pada mesin bordir, penguasaan teknologi akan menjadi ketrampilan utama bagi para pekerja. Hal ini menuntut pekerja melakukan upaya penguasaan mesin bordir komputer dan menyelesaikan pesanan tepat waktu. Upaya ini mempertegas simpulan bahwa pilihan untuk memperbaiki kualitas ketrampilan pekerja dengan mesin baru menjadi pilihan utama agar mereka tetap dapat bekerja. Peran mereka berimbang dengan kebutuhan penggunaan teknologi pada mesin produksi.

Hasil penelitian ini menyarankan pengusaha agar senantiasa menggunakan inovasi produksi melalui penggunaan teknologi, walaupun dalam pilihan tersebut akan memaksa pekerja untuk memperbaiki ketrampilan mereka melalui pelatihan kerja tentang disain dan ketrampilan lainnya yang dilakukan oleh dinas terkait, seperti Dinas Perindustrian dan Perdagangan serta Dinas Koperasi dan Usaha Mikro, Kecil, dan Menengah. Selain itu, program perbaikan ketrampilan pekerja dapat juga diadakan oleh asosiasi pengusaha bordir. Program pelatihan tersebut bertujuan untuk meningkatkan 
kualitas dan daya saing produk. Keterbatasan penelitian ini terletak pada obyek penelitian dan metode analisis yang fokus pada persoalan terkait peran teknologi dan tenaga kerja dalam kompleksitas situasi lingkungan bisnis yang dihadapi oleh perusahaan bordir. Penelitian selanjutnya dapat mengembangkan isu lebih jauh terkait efisiensi biaya atas pilihan penggunaan teknologi dan upah secara kuantitatif.

\section{DAFTAR REFERENSI}

Anoraga, P. (2007). Pengantar Bisnis: Pengelolaan Bisnis dalam Era Globalisasi. Jakarta: Rineka Cipta.

Bas, M., \& Berthou, A. (2017). Does Input-trade Liberalization Affect Firms' Foreign Technology Choice? The World Bank Economic Review, 31(2), 351-384.

Chaoji, P., \& Martinsuo, M. (2019). Creation Processes for Radical Manufacturing Technology Innovations. Journal of Manufacturing Technology Management, 30 (7), 1005-1033.

Chiarvesio, M., \& Romanello, R. (2018). Industry 4.0 Technologies and Internationalization: Insights from Italian Companies. International Business in the Information and Digital Age, 30(1), 357-378.

Creswell, J. W. (2010). Mapping the Developing Landscape of Mixed Methods Research. SAGE Handbook of Mixed Methods in Social \& Behavioral Research, 2, 45-68.

Danquah, M., \& Amankwah-Amoah, J. (2017). Assessing the Relationships between Human Capital, Innovation and Technology Adoption: Evidence from SubSaharan Africa. Technological Forecasting and Social Change, 122, 24-33.

Deming, D. J. (2017). The Growing Importance of Social Skills in the Labor Market. The Quarterly Journal of Economics, 132(4), 1593-1640.

Feder, C. (2018). The Effects of Disruptive Innovations on Productivity. Technological Forecasting and Social Change, 126(C), 186-193.

Flachenecker, F. (2018). The Causal Impact of Material Productivity on Macroeconomic Competitiveness in the European Union. Environmental Economics and Policy Studies, 20(1), 17-46.

Goos, M. (2018). The Impact of Technological Progress on Labour Markets: Policy Challenges. Oxford Review of Economic Policy, 34(3), 362-375.

Hagsten, E., \& Sabadash, A. (2017). A Neglected Input to Production: The Role of ICTschooled Employees in Firm Performance. International Journal of Manpower, 38(3), 373-391.

Hasibuan, M. S. P., \& Hasibuan, H. M. S. P. (2016). Manajemen Sumber Daya Manusia. Jakarta: Bumi Aksara.

ILO (2013). Decent Work Country Profile: Bangladesh. Geneva: ILO Cataloguing in Publication Data.

Jacinto, P. d. A., Ribeiro, E. P., \& Cravo, T. (2017). A Closer Look at the Skilled Labor Demand Increase in Brazil, Journal of Economic Studies, 44(2), 294-312.

Mallick, S. K., \& Sousa, R. M. (2017). The Skill Premium Effect of Technological Change: New Evidence from United States Manufacturing. International Labour Review, 156(1), 113-131. 
Mariyono, J. (2018). Productivity Growth of Indonesian Rice Production: Sources and Efforts to Improve Performance. International Journal of Productivity and Performance Management, 67(9), 1792-1815.

Muhardi, M. \& Lies, S. H. (2007). Management of Regional Economics Development. Majalah Ekonomi, XVII(1), 80-90.

Morris, D. M. (2018). Innovation and Productivity among Heterogeneous Firms. Research Policy, 47(10), 1918-1932.

Özçam, A. (2019). The Economic Market Outcomes and Income Distribution when Capital is not Homogeneous. Journal of Industry-University Collaboration, 1(1), $38-56$.

Porter, M. E. (2011). Competitive Advantage of Nations: Creating and Sustaining Superior Performance. New York: Simon and Schuster World Press.

Riyadi, S., \& Sumardi, S. (2017). The Impact of Innovation Strategy toward Business Competitiveness of Manufacturing Industry in Surabaya, Indonesia. Hasanuddin Economics and Business Review, 1(1), 83-89.

Robbins, S. P. (2006). Perilaku Organisasi. Jakarta: PT Indeks (Kelompok Gramedia).

Romão, J., \& Nijkamp, P. (2019). Impacts of Innovation, Productivity and Specialization on Tourism Competitiveness - A Spatial Econometric Analysis on European Regions. Current Issues in Tourism, 22(10), 1150-1169.

Rosenberg, N., \& Nathan, R. (1982). Inside the Black Box: Technology and Economics. New York: Cambridge University Press.

Schilling, M. A. (2015). Manajemen Strategis Inovasi Teknologi. Yogyakarta: Pustaka Pelajar.

Sentosa, E., \& Trianti, E. (2019). Pengaruh Kualitas Bahan Baku, Proses Produksi dan Kualitas Tenaga Kerja terhadap Kualitas Produk pada PT Delta Surya Energy di Bekasi. Oikonomia: Jurnal Manajemen, 13(2), 62-71.

Stojcic, N., Hashi, I., \& Orlic, E. (2018). Creativity, Innovation Effectiveness and Productive Efficiency in the UK. European Journal of Innovation Management, 21(4), 564-580.

Sumihardjo, T. (2008). Penyelenggaraan Pemerintah Daerah melalui Pengembangan Daya Saing Berbasis Potensi Daerah. Jakarta: Fokusmedia.

Wibowo, S. A., \& Nugroho, S. B. M. (2018). Analisis Faktor-faktor yang Mempengaruhi Produksi Industri Pengolahan dan Efisiensi Produksi pada Kabupaten/Kota di Jawa Tengah Tahun 2010-2015. Media Ekonomi dan Manajemen, 33(2), 205-213.

Wiltshire, A. H. (2018). Labour Turnover and Considerations around Work: Temporary Farm Workers in South-Africa. International Journal of Sociology and Social Policy, 38(1), 2-25. 